\title{
HYBRIDS OF RYEGRASSES \\ AND MEADOW FESCUE AND THEIR \\ VALUE FOR GRASS BREEDING
}

MET SAMENVATTING

BASTAARDEN VAN RAAIGRASSEN EN BEEMDLANGBLOEM

EN HUN BETEKENIS VOOR DE GRASSENVEREDELING

F. WIT

MEDEDELING No. 21

VAN DE

STICHTING VOOR PLANTENVEREDELING

OVERDRUK UIT EUPHYTICA 8 (1959): 1-12

265331 


\section{STICHTING VOOR PLANTENVEREDELING, S.V.P. \\ NUDE 66, WAGENINGEN}

Ir. J. I. C. BuTLER, te Wageningen

Di. Ir. J. P. Dudok van HeEl, te Naarden

Prof. Ir. M. L't HART, te Wageningen

Ir. D. J. v. D. HAVE, te Kapelle-Biezelinge

Ir. J. W. LACKAMP, te Ottersum

Ir. G. W. MEYER, te Leeuwarden

A. VISSER, te Dordrecht

Prof. Dr. Ir. J. C. DoRst, te Wageningen

Ir. P. A. DEN ENGELSE, te 's-Gravenhage

\section{BESTUUR}

- voorzitter, als lid rechtstreeks benoemd door de Minister

vice-voorzitter, benoemd op voordracht van de Nederlandse Kwekersbond

- secretaris, benoemd op voordracht van de Senaat van de Landbouwhogeschool

- lid, benoemd op voordracht van de Nederlandse Kwekersbond

- lid, benoemd op voordracht van de Nederlandse Kwekersbond en Landbouwschap samen

- lid, benoemd op voordracht van de Nederlandse Algemene Keuringsdienst

- lid, benoemd op voordracht van het Landbouwschap

- adv. lid, benoemd op voordracht van het Bestuur van de S.V.P.

- adv. lid, benoemd op voordracht van het Bestuur van de S.V.P.

\section{STAF}

Dr. Ir. F. E. NiJdaM

- Directeur

DR. Ir. H. LAMBERTS

- Adjunct-Dìrecteur

Dr. Ir. C. A. HuIJSMAN

Ir. G. A. THIJN

Ir. H. T. WIERSEMA

Dr. F. WIT

Ir. G. E. vaN DIJK

Ir. J. DIJKSTRA

Ir. G. CLEIJ

Ir. D. KLOEN

Dr. Ir. G. Dantuma

Ir. J. MESDAG

Dr. Ir. H. LAMBERTS

Ir. K. HOEN Ph. D.

Ir. H. T. WIERSEMA

G. J. SPECKMANN

A. J. GLERUM

J. Holman

M. H. AgELINK

2
Aardappelveredeling

Grassen- en Klaververedeling

Voeder- en Suikerbietenveredeling

Tarwe-, gerst- en haververedeling

Zoete lupinen-, stoppelknollen-, wikken-, serra-

della-, landbouwstambonen-, en erwtenveredeling

- Vlas- en koolzaadveredeling

- Cytologie

- Bedrijfsleider Proefboerderij Prof. Broekemahoeve, Marknesse (N.O.P.)

- Bedrijfsleider te Wageningen

- Hoofd Algemene Zaken 


\title{
HYBRIDS OF RYEGRASSES AND MEADOW FESCUE AND THEIR VALUE FOR GRASS BREEDING
}

\author{
F. WIT \\ Foundation for Agricultural Plant Breeding, Wageningen \\ Received 21 Nov. 1958
}

\begin{abstract}
1. In attempts to intercross Lolium perenne and L. multiflorum with Festuca pratensis in a glasshouse, 13,284 emasculated flowers of diploid, triploid and tetraploid Lolium plants were provided with pollen of diploid and tetraploid Festuca plants. Only the combinations $2 n \times 4 n$ and $3 n \times 4 n$ produced hybrids, viz. on average 5.3 and 1.0 mature hybrid plants per 100 pollinated flowers. In crosses performed in winter these averages were 12.0 and 4.9 respectively.

2. Non-emasculated spikes of diploid, triploid and tetraploid plants of $L$. perenne and $L$. multiflorum in the field were enclosed in pergamine bags with panicles of diploid, triploid and tetraploid plants of $F$. pratensis. Apart from the above-mentioned combinations hybrids were also obtained of the crosses $2 n \times 2 n$ and $2 n \times 3 n$. The number of hybrids produced per infiorescence was on average nearly as high as in corresponding crosses in the glasshouse.

By bagging together spikes of self-incompatible diploid plants of $L$. perenne and $L$. multiflorum with panicles of tetraploid plants of $F$. pratensis in the field, large numbers of triploid hybrid seeds may easily be obtained. This opens the possibility of using seed treatment with colchicine for the production of hexaploids.

3. Triploid hybrids showed a better production in spring and a better aftermath growth in summer than either parent plants. Spontaneously obtained hybrids were more winterhardy than most winterhardy indigenous types of perennial ryegrass.

4. All artificial and most natural hybrids had no dehiscent anthers; the percentage of normal pollen varied in the artificial hybrids from 0 to $3.8 \%$, in the natural hybrids from 0 to $10 \%$. Several plants in both groups were slightly female fertile. Some plants with hybrid characters, collected from natural grassland, had dehiscent anthers and more than $75 \%$ stainable pollen; their female fertility was fairly good.

5. Open pollinated seeds of triploid male sterile hybrids produced, apart from a majority of plants closely resembling the parent species, or the $F_{1}$ hybrids, also types with new combinations of characters. The male fertility was considerably higher than in the previous generation: several plants had dehiscent anthers. In spontaneous families of the male fertile hybrid forms greatly deviating types of Lolium occurred.
\end{abstract}


6. Some possibilities of the various cross combinations for the breeding of ryegrasses are discussed.

\section{INTRODUCTION}

Several species of the genus Lolium are important for grassland husbandry and for the production of fodder grasses. In permanent pastures and in leys of two years and longer perennial ryegrass (Lolium perenne L.) is the most valued grass species. For the establishment of one to two year leys Italian ryegrass ( $L$. multiflorum LAM.) and its annual form Westerwolths ryegrass are the most important grasses. All these ryegrass types excel in aggressiveness, high fodder value and great palatability. However, they exhibit some deficiences which within the species are difficult to eliminate. In severe winters Italian ryegrass is often destroyed by frost; of perennial ryegrass even the indigenous types can be damaged to such an extent that a severely retarded growth in spring and a reduced contribution to the sward are the result. Other deficiences of this species are a suppression of white clover in mixtures and a low production in midsummer.

Meadow fescue (Festuca pratensis HuDs.) is less palatable and forms a more open sward as compared with perennial ryegrass, but it is more hardy in winter and more productive in summer. The species is very tolerant towards white clover and the less aggressive grasses such as timothy.

Plants with combinations of the favourable characters of ryegrasses $(2 n=14)$ and meadow fescue $(2 n=14)$ would offer new possibilities for grassland husbandry. In places where the two species occur side by side intermediate types are not rare. These types are considered as hybrids and are described under the names of Festulolium and Festuca loliacea CURT.

In several cases attempts to produce hybrids by means of artificial crossing have been successful. In broad outline these hybrids were similar to those found in nature. The most elaborate investigations in this field have been carried out by JENKIN $(4,10)$. The publication mentioned under 4 in the references gives a survey of the older literature.

\section{LITERATURE}

By reciprocal crossing of $L$. perenne and $F$. pratensis, JENKIN (10) obtained from approximately 8,000 emasculated flowers in total 12 mature $F_{1}$ hybrids. They were all diploid, male sterile and very weakly female fertile. Backcrossing to $L$. perenne yielded $19 \mathrm{~F}_{2}$ plants. Most of them could not be distinguished from perennial ryegrass and were normally fertile. Some resembled this type in outward appearance but showed a reduced fertility. One plant had a clearly deviating appearance and was to a slight extent both male and female fertile; on cytological examination it was found to be a triploid. The two first-mentioned groups of backcross hybrids in further crosses behaved as normal plants of $L$. perenne. In some cases, however, there were strong indications that they carried some genes of $F$. pratensis and transferred these to their offspring. The triploid plant, after crossing with $L$. perenne, produced offspring with a wide range of variation in type. 
CROWDER (2) crossed L. perenne and L. multiflorum with $F$. pratensis, excised the young embryos from the seeds and grew them on nutrient agar. In spite of his precautions only $0.3 \%$ of these crosses resulted in hybrid plants. He obtained two hybrids which produced no offspring.

CARNAHAN and Hill (1) crossed diploid $L$. perenne with tetraploid $F$. pratensis. Some hundreds of emasculated flowers produced 12 triploid hybrids. These grew more vigorous and were leafier than the parent plants, but they appeared to be highly sterile. By treatment of rooted tillers with colchicine the authors obtained an autoallohexaploid from every triploid. It was expected that the hexaploids would possess a higher fertility than the triploids.

ESsaD (3), also by colchicine treatment of tillers, obtained two amphidiploids from two diploid hybrids. The percentage of stainable pollen was 1.3 in the triploid, nearly 40 in the amphidiploids. This would be an indication of the possibility to create fertile amphidiploids.

From the literature it appears to be possible to produce diploid and triploid hybrids and to create from these hybrids amphidiploids and autoallohexaploids by means of colchicine-treatment. Attempts to utilize these hybrids for practical breeding purposes may therefore be undertaken on a diploid, a tetraploid and a hexaploid level.

In all these cases it is desirable to combine a large number of genotypes of the parent species and to study the results of these combinations. This is only feasible when large numbers of hybrids can be obtained with relatively little work. The emasculation and pollination of thousands of florets and the production of amphidiploids and hexaploids by means of tiller-treatment are too laborious for practical application. A mass production of diploid and triploid hybrid seeds would enable us to apply seed treatment and to produce allopolyploids in an easier way and in larger numbers.

Crosses of the parent species on tetraploid level and crosses of tetraploids of one species with octoploids of the other might produce amphidiploids and hexaploids directly.

Finally a collection of hybrid types occurring in nature would constitute valuable supplementation of the experimental hybrids.

The above-mentioned possibilities are now studied more closely. The preliminary results of this investigation are given below.

\section{THE PRODUCTION OF HYBRIDS}

In the years 1955, 1956 and 1957 attempts were made to cross selected clones of $L$. perenne and $L$. multiflorum as female parents with clones of $F$. pratensis as male parents. For this purpose 20 diploids, 3 triploids and 33 tetraploids of Lolium were used; of Festuca these numbers were 8,1 and 18 respectively.

The tetraploid clones were selected from $C_{1}$ and $C_{2}$ seedlings, obtained after colchicine treatment. The triploids were derived from $\mathrm{C}_{0}$ plants by means of spontaneous pollination.

In the glasshouse 103 crosses were made by emasculating and pollinating 13,284 florets of 324 inflorescences. The seeds obtained were germinated on moist filter-paper and then planted in flats in the glasshouse. The resulting plants were planted in the field in the spring. The results of these glasshouse crosses are tabulated below. 
Table 1. Some Results of Crosses Between Ryegrasses and meadow fescue in the gLASSHOUSE

\begin{tabular}{c|c|c|c|c|c|c|c|c|c}
\hline \multicolumn{2}{c|}{ Parent plants } & $\begin{array}{c}\text { Number } \\
\text { of } \\
\text { crosses }\end{array}$ & $\begin{array}{c}\text { Number } \\
\text { of } \\
\text { spikes }\end{array}$ & $\begin{array}{c}\text { Number } \\
\text { of } \\
\text { seeds }\end{array}$ & \multicolumn{2}{|c|}{$\begin{array}{c}\text { Number of } \\
\text { plants }\end{array}$} & $\begin{array}{c}\text { Number } \\
\text { of suc- } \\
\text { cessful } \\
\text { crosses }\end{array}$ & $\begin{array}{c}\text { Number of } \\
\text { hybrids per } \\
\text { successful } \\
\text { cross }\end{array}$ & $\begin{array}{c}\text { Number } \\
\text { of hybrids } \\
\text { per } \\
\text { spike }\end{array}$ \\
\hline Lolium & Festuca & Lolium & Hybrids & & & & & \\
$2 n$ & $2 n$ & 18 & 58 & 6 & 4 & - & - & - & - \\
$2 n$ & $4 n$ & 21 & 64 & 188 & 5 & 138 & 10 & 13.8 & 4.1 \\
$3 n$ & $2 n$ & 2 & 6 & - & - & - & - & - & - \\
$3 n$ & $4 n$ & 9 & 26 & 19 & 1 & 11 & 3 & 3.7 & 1.0 \\
$4 n$ & $2 n$ & 17 & 52 & 3 & 2 & - & - & - & - \\
$4 n$ & $4 n$ & 36 & 118 & 5 & 3 & - & - & - & -
\end{tabular}

From this table it is apparent that the crosses were successful only when diploid and triploid Lolium plants were pollinated with pollen of tetraploid meadow fescue. Of the first-mentioned combination on an average 5.3 mature hybrids were obtained per 100 florets. If the crosses which were not successful, for instance through incompatibility of the parental genotypes, are left out of consideration, $10 \%$ of the pollinated florets yielded hybrid plants. Part of these crosses were carried out in winter after flowering had been induced by long day treatment. Under these circumstances the combinations Lolium $2 \mathrm{n} \times$ Festuca $4 \mathrm{n}$ produced on average 12.0 hybrids per 100 florets. The four most successful crosses produced 151 seeds $(30.6 \%$ ) on 492 florets; the seeds gave 116 mature plants, all of them hybrids. So in the most favourable cases 23.6 mature hybrid plants were obtained per 100 emasculated florets. The 15 Lolium seedlings are all derived from crosses made in summer. Presumably they resulted from spontaneous pollination by air-borne Lolium pollen, since the glasshouses could not be closed hermetically.

A number of crosses, partly made by means of the same parent plants, was tested in the field in summer by simply bagging together the non-emasculated inflorescences of both parent species. In the bags the inflorescences of the Festuca parents were always in positions above those of the Lolium parents, so that conditions were less favourable for the reciprocal crosses. As, moreover, sometimes inflorescences of meadow fescue had to be used which already showed a beginning of flowering, as a rule only the seeds produced by Lolium ears were sown. The results of the field crosses are presented in table 2.

TABLE 2. SOME RESUlTS OF CROSSES OF RYEGRASSES AND MEADOW FESCUE IN THE FIELD

\begin{tabular}{|c|c|c|c|c|c|c|c|c|c|}
\hline \multicolumn{2}{|c|}{ Parent plants } & \multirow{2}{*}{$\begin{array}{l}\text { Number } \\
\text { of } \\
\text { crosses }\end{array}$} & \multirow{2}{*}{$\begin{array}{c}\text { Number } \\
\text { of } \\
\text { spikes }\end{array}$} & \multirow{2}{*}{$\begin{array}{c}\text { Number } \\
\text { of } \\
\text { seeds }\end{array}$} & \multicolumn{2}{|c|}{$\underset{\text { plants }}{\text { Number of }}$} & \multirow{2}{*}{$\begin{array}{l}\text { Number } \\
\text { of suc- } \\
\text { cessful } \\
\text { crosses }\end{array}$} & \multirow{2}{*}{$\begin{array}{l}\text { Number of } \\
\text { hybrids per } \\
\text { successful } \\
\text { cross }\end{array}$} & \multirow{2}{*}{$\begin{array}{c}\text { Number } \\
\text { of hybrids } \\
\text { per } \\
\text { spike }\end{array}$} \\
\hline Lolium & Festuca & & & & Lolium & Hybrids & & & \\
\hline $2 n$ & $2 n$ & 3 & 17 & 30 & 14 & 1 & 1 & 1.0 & 0.2 \\
\hline $2 n$ & $3 n$ & 1 & 6 & 73 & 20 & 8 & 1 & 8.0 & 1.3 \\
\hline $2 n$ & $4 n$ & 15 & 61 & 382 & 19 & 156 & 10 & 15.6 & 3.6 \\
\hline $3 n$ & $3 n$ & 1 & 3 & 7 & 5 & - & - & - & - \\
\hline $3 n$ & $4 n$ & 2 & 7 & 10 & - & 4 & 1 & 4.0 & 1.3 \\
\hline $4 n$ & $2 n$ & 1 & 2 & 1 & 1 & - & - & - & - \\
\hline $4 n$ & $4 n$ & 6 & 31 & 34 & 11 & - & - & - & - \\
\hline
\end{tabular}


From this table it is clear that the baggings $2 n \times 4 n$ and $3 n \times 4 n$ without emasculation produced about the same number of hybrids per spike as the crosses with emasculation and artificial pollination.

Although only a few combinations $2 n \times 2 n$ and $2 n \times 3 n$ were bagged, in both cases one cross was successful. The combinations $4 n \times 4 n$ and $4 n \times 2 n$ produced neither in the glasshouse nor in the field a single hybrid plant.

The number of hybrids from seeds of Festuca panicles will be no exact standard for the prospective success of the reciprocal crosses. However, the hybrids obtained in some cases show that certain cross combinations are possible. For instance four hybrids were obtained from 40 panicles of tetraploid meadow fescue which had been bagged together with ears of diploid Lolium plants. In the combination Festuca $3 n \times$ Lolium 2 five panicles produced three hybrids, whereas the combination Festuca $2 \mathrm{n} \times$ Lolium $4 \mathrm{n}$ resulted in one hybrid from six panicles.

By treating tetraploid seeds with colchicine-solutions some octoploid plants were obtained in $L$. perenne, L. multiflorum and $F$. pratensis. So far no crosses have been made with these octoploids.

\section{THE CHARACTERS OF THE $\mathrm{F}_{1}$-HYBRIDS}

\section{Morphological characteristics}

When $L$. perenne was used as the female parent the hybrids could be easily distinguished from seedlings resulting from selfing by the "rolled" emergence of the youngest leaf, by the shorter ligule and by the broader leaf blade. This distinction was much more difficult when Italian ryegrass was used as the pistillate parent plant. However, it did not present any difficulties as soon as the plants started heading. Although the hybrids in a vegetative condition had a somewhat different appearance from meadow fescue, in many cases they could not be distinguished from the latter before the heading stage.

As a thorough investigation of our hybrids has not been carried out so far, only the most conspicuous characteristics will be mentioned here.

Descriptions of diploid $F_{1}$-hybrids have been given by JENKIN (10), of triploid $F_{1^{-}}$ hybrids by CARNAHAN and Hill (1). Judging from these descriptions and from our own observations, the influence of Lolium parent on mature plant characters is less pronounced in the triploid than in the diploid hybrids.

The inflorescence of the triploid hybrids is intermediate between the spike of Lolium and the panicle of Festuca. As a rule the lower nodes carry a side-rachis with 3 to 5 spikelets; towards the tip spikelets occur singly at the nodes. Only in weak plants and in weak tillers the infiorescences are sometimes unbranched. Also in these cases, however, they can easily be distinguished from pure Lolium spikes by their laxer structure and by the festucoid appearance of the spikelets. These are not compressed as in Lolium, but more cylindrical as in Festuca, elongated, rather lax and multiflowered. There are usually two glumes in the lateral spikelets, whereas there is only one in Lolium.

\section{Vigour}

The general impression is that the hybrids grow more vigorously than either parent. 
In the first preliminary trials in which the former were compared with seedlings or clones of the parent plants, they distinguished themselves by more leaf production in the spring.

In table 3 the data of some of these trials have been summarized. The leaf production was estimated on 1 May 1958 according to a scale of 2 (very low) to 9 (very high). The figures for the aftermath growth in summer in rough outline exhibited the same trend.

TABle 3. FREQUENCY DISTRIBUTION FOR SPRING PRODUCTION OF DIPLOID PLANTS OF PERENNIAL RYEGRASS, OF TETRAPLOID PLANTS OF MEADOW FESCUE AND OF THEIR TRIPLOID HYBRIDS

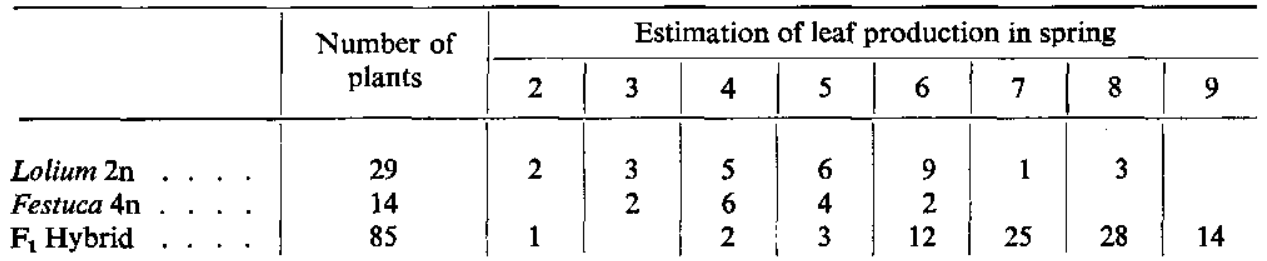

So far no data are available of the winterhardiness of the artificial hybrids. Some spontaneous hybrids which were collected in 1955, in the winter of $1955 / 56$ appeared to be equally winterhardy as indigenous plants of meadow fescue and to surpass clearly the best clones of perennial ryegrass in this respect. It was remarkable that a Festulolium hybrid which was obtained by spontaneous fertilization of a hybrid between perennial and Westerwolths ryegrass also showed a very high degree of winterhardiness.

\section{Fertility}

All artificial hybrids had non-dehiscent anthers; they were male sterile. The contents of pollen sacs of 17 plants were stained with aceto-carmine and observed through the microscope. In three hybrids of the cross Lolium $2 \mathrm{n} \times$ Festuca $3 \mathrm{n}$ not a single normallooking pollen grain was found. In 14 hybrids between diploid Lolium and tetraploid meadow fescue the percentage "good" pollen varied from 0 to 3.8 .

In order to gain an impression of the female fertility, some spontaneously pollinated inflorescences of a number of hybrids were collected. In general seed setting appeared to be very poor, but of various hybrids between diploid Lolium and tetraploid Festuca a few dozens of seeds were obtained. They produced in total 31 mature plants.

\section{HYBRID TYPES IN NATURAL GRASSLAND}

As was already mentioned not seldom intermediate forms are found in places where $L$. perenne and $F$. pratense occur side by side. They seem to prefer the ditch-sides of meadows, but they are also found on other places in pastures and along way-sides. When in flower they can be easily distinguished from the pure species and largely resemble the artificial hybrids.

In total 93 of these intermediate types were collected from six habitats. On the basis of their outward appearance and their behaviour they could be grouped into two categories. 
The largest group comprised types as collected by JENKIN in Great Britain, variable in habit, in culm size, in degree of branching of the inflorescences and in leaf size. Plants from the same habitat were almost similar in their characters.

A small group of vigorous individuals derived from a meadow bordering the Kaagse Plassen (a lake near Warmond - province of South-Holland) differed from the first group in that the plants produced unbranched spikes even on the most vigorous tillers. They evidently deviated from $L$. perenne by their very lax inflorescences and by the cylindrical festucoid spikelets which were usually subtended by two glumes. On cytological examination they appeared to be triploid.

The pollen of 87 plants of the first group was examined; 75 plants produced less than $1 \%$ normal pollen; in 12 plants this percentage varied from 1 to 10 . In all these cases the anthers were non-dehiscent so that the plants were male sterile. However, the three plants derived from De Kaag had dehiscent anthers with 76-79\% normal pollen. Triploids of this type have not yet been found in nature, as far as the author is aware.

Seeds from open pollinated inflorescences were harvested from six of the firstmentioned male sterile hybrids; on cytological examination these plants were found to be triploids. The seeds produced 70 mature plants.

The three male fertile plants from de Kaag yielded a large number of seeds from which 650 plants were raised. Consequently plants of both groups can be used for the production of following generations. However, more investigations are needed to ascertain which plants are desirable as male parents.

\section{Plants of The SECOND generation}

Only part of the spontaneously produced plants of the second generation has flowered so far; therefore only a few observations could be made and their results have only a preliminary value. The data on male fertility have been summarized in table 4 .

Table 4. Male fertility of Natural and artificial Hybrids aNd OF their open pollinated PROGENIES

\begin{tabular}{|c|c|c|c|c|c|c|}
\hline \multirow{2}{*}{ Material } & \multirow{2}{*}{$\begin{array}{l}\text { Number } \\
\text { of plants } \\
\text { examined }\end{array}$} & \multicolumn{3}{|c|}{ Percentage of stainable pollen } & \multicolumn{2}{|c|}{1 Anthers } \\
\hline & & Minimum & Maximum & Average & $\begin{array}{c}\text { Non- } \\
\text { dehiscent }\end{array}$ & Dehiscent \\
\hline $\mathrm{F}_{1}$ Lolium $2 \mathrm{n} \times$ Festuca $4 \mathrm{n}$. & 14 & 0.0 & 3.8 & 1.3 & 14 & 0 \\
\hline $\mathrm{F}_{2}$ Lolium $2 \mathrm{n} \times$ Festuca $4 \mathrm{n}$ & 8 & 0.0 & 99.3 & 20.6 & 7 & 1 \\
\hline Natural hybrids Wageningen . & 9 & 0.0 & 2.3 & 0.8 & 9 & $\mathbf{0}$ \\
\hline$F_{1}$ Natural hybrids Wageningen & 18 & 6.1 & 98.0 & 70.0 & 3 & 15 \\
\hline Natural hybrids de Kaag . . & 3 & 75.7 & 78.5 & 77.0 & 0 & 3 \\
\hline$F_{1}$ Natural hybrids de Kaag . & 19 & 0.0 & 87.9 & 55.2 & 5 & 14 \\
\hline
\end{tabular}

From this table it is clear that in the offspring of the artificial triploid hybrids the pollen fertility has greatly increased and in one case has become quite normal. In the offspring of the male sterile natural hybrids there was a far greater improvement of the pollen fertility; 15 plants had more than $46 \%$ "good" pollen and fully dehiscent anthers. In the two plants with less than $40 \%$ "good" pollen the anther-lobes 
remained completely closed, while in one plant with $41 \%$ "good" pollen they were partially dehiscent. This suggests that the anthers may be able to shed pollen when the percentage of normal pollen grains rises above a value of about 40 .

The data from table 4 show that both the artificial and the natural triploid male sterile hybrids carry the potentiality of producing male-fertile types in their offspring. The value of such derivative types for practical breeding purposes will depend on the question whether they combine valuable genes from both parent species and whether they transfer such combinations to their progeny. In the present stage of the investigation this cannot be stated conclusively. However, a preliminary study of the material gives some indications in this direction.

In the offspring of the artificial hybrids seven individuals could not be distinguished morphologically from Lolium plants, two were similar to Festuca pratensis and four closely resembled the $F_{1}$ plants. In addition two Festuca plants occurred with awned glumes and two plants which showed inner glumes as a constant feature but were otherwise completely Lolium types.

Most derivatives of the male sterile natural hybrids were morphologically not clearly distinguishable from $L$. perenne or $F$. pratensis. A plant which had a very close resemblance to Lolium had the short ligule of meadow fescue.

Among the offspring of the plants derived from de Kaag only one individual was found with the characters of meadow fescue. The inflorescences of the other flowering plants all conformed well to the Lolium perenne type. However, there was far wider variation in plant type than that observed in earlier collections of thousands of plants sampled from various types of grasslands in the Netheriands. Apart from plants with very broad leaves there were other types with extremely narrow ones, resembling those from Festuca rubra. Such plants also occurred in some progenies from male-sterile spontaneous hybrids, though in smaller number. They corresponded in many respects to the description of JENKIN's plant 92-bE-2, obtained by crossing the triploid plant from his first backcross generation with L. perenne (JENKIN, 10).

\section{DISCUSSION OF THE RESULTS}

The data of tables 1 and 2 indicate that the breeding affinity of $L$. perenne and $L$. multiflorum with Festuca pratensis largely depends on the chromosome-numbers of the parent plants. For a closer examination of this question the results of the crosses have been summarized in table 5 .

Although the various combinations are represented very disproportionately, the data of table 5 are a strong indication that by using Lolium plants as the female parents the crosses will be more successful as the number of Festuca chromosomes approaches more the double number of the Lolium chromosomes.

According to CROwDer (2) and JenkIN (10), after crossing diploid plants of $L$. perenne and $L$. multiflorum with $F$. pratensis, an embryo is often initiated. However, there is usually no further development and no germination of the seed, since no 
Table 5. Relation Between the Chromosome-number of the Parent plants and the Number of HYBRIDS FOUND

\begin{tabular}{|c|c|c|c|c|c|c|c|}
\hline \multicolumn{2}{|c|}{ Parent plants } & \multirow{2}{*}{$\begin{array}{l}\text { Ratio of } \\
\text { Festuca and } \\
\text { Lolitum } \\
\text { chromosomes }\end{array}$} & \multicolumn{2}{|c|}{ Number of crosses } & \multirow[b]{2}{*}{$\begin{array}{c}\text { Number } \\
\text { of hybrids }\end{array}$} & \multicolumn{2}{|c|}{ Number of hybrids } \\
\hline Festuca & Lolium & & Total & Successful & & $\begin{array}{c}\text { Per } \\
\text { successful } \\
\text { cross }\end{array}$ & $\begin{array}{l}\text { Per } \\
\text { spike }\end{array}$ \\
\hline $4 n$ & $2 n$ & $2.0: 1$ & 36 & 20 & 294 & 14.7 & 4.2 \\
\hline $3 n$ & $2 n$ & $1.5: 1$ & 1 & 1 & 8 & 8.0 & 1.3 \\
\hline $4 n$ & $3 n$ & $1.3: 1$ & 9 & 4 & 15 & 3.8 & 1.1 \\
\hline $2 n$ & $2 n$ & $1.0: 1$ & 20 & 1 & 1 & 1.0 & 0.2 \\
\hline $3 n$ & $3 n$ & $1.0: 1$ & 1 & - & - & - & - \\
\hline $4 n$ & $4 n$ & $1.0: 1$ & 42 & - & - & - & - \\
\hline $2 n$ & $4 n$ & $0.5: 1$ & 18 & - & - & - & - \\
\hline
\end{tabular}

normal endosperm is produced. If the seeds germinate, the seedlings are very weak at first. Only in one case JENKIN obtained a hybrid which grew more vigorously from the beginning. It was produced by a well-developed seed which apparently had possessed normal endosperm and which had originated by pollination of meadow fescue with a mixture of ryegrass and meadow fescue pollen. JENKIN presumes that in this case male gametes of both species have entered the embryo sac. One of the Lolium gametes is supposed to have conjugated with the egg cell to lay the foundation of the hybrid embryo. The development of the endosperm would be due to a conjugation of the $F$. pratensis fusion nucleus with a gamete of meadow fescue. The fact that this particular cross did not produce meadow fescue seeds is an indication that the gametes of perennial ryegrass penetrated more rapidly than those of meadow fescue and thus rendered impossible a fertilization of the egg cells by the meadow fescue gametes.

By connecting the data of table 5 with the formation of endosperm they can be interpreted in the following way: A haploid Festuca gamete cannot conjugate with the diploid fusion nucleus of Lolium, or the triple nucleus is not capable of inducing a normal formation of endosperm. A diploid Festuca gamete combines fairly easily with the diploid fusion nucleus of Lolium and the nucleus produced - presumably tetraploid - effects a normal endosperm production. Triploid plants of meadow fescue may partly form superhaploid or subdiploid gametes which in this respect might be intermediate between haploid and diploid gametes.

Two sets of chromosomes of $F$. pratensis apparently have a similar - though weaker - effect than one set of Lolium chromosomes. The question now arises how the male gametes of the natural polyploids of the genus Festuca behave in crosses with Lolium. Table 6 presenting some results of the extensive breeding experiments of JENKIN $(4,5$, $6,7,8,9,10)$ partly answers this question.

In these crosses also the number of viable seeds produced appears to be larger as the number of chromosomes of the father plant is increased. As under favourable conditions pollination of diploid Lolium by tetraploid $F$. pratensis plants produced on average 12.0 hybrids per 100 florets, it can be concluded that 14 chromosomes of $F$. pratensis are about as effective as 21 chromosomes of $F$. arundinacea, more effective 
TABLE 6. ReLATIONS hetWEen the NUMBER OF CHROMOSOMES OF THE FATHER PLANTS AND THE PERCENTAGE OF GERMINATED SEEDS AFTER CROSSING Lolium perenne WITH VARIOUS Festuca SPECIES

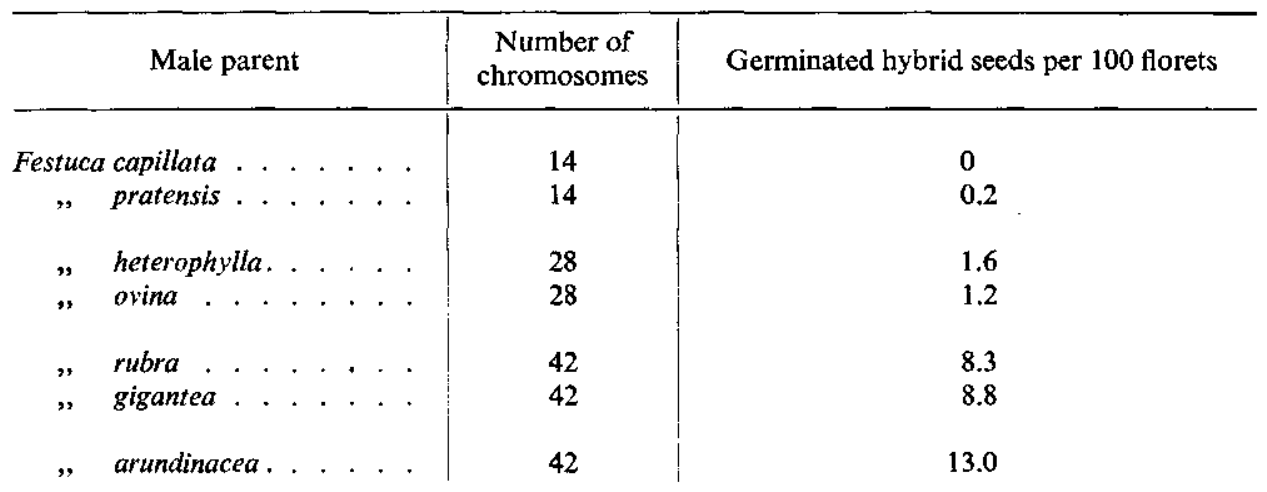

than 21 chromosomes of $F$. rubra and $F$. gigantea, and much more effective than 14 chromosomes of $F$. ovina and $F$. heterophylla. This gives the impression that the breeding affinities are less determined by the ratio between the number of chromosomes than by the ratio of homologous chromosomes, chromosome segments, or particular genes. Further speculations in this field, however, are beyond the scope of this paper.

The most important practical result of the breeding experiments is that hybrids of Lolium and $F$. pratensis can be easily produced on a large scale, by bagging together non-emasculated inflorescences of self-incompatible diploid Lolium plants and panicles of tetraploid $F$. pratensis. In selecting intercompatible parents, 5 to 10 hybrids per spike could be obtained. In as far as such hybrids were examined cytologically, they appeared to be triploids. Treatment of the germinated seeds with colchicine will then produce hexaploids. The laborious tiller treatment can be avoided and each duplication will result in a new hexaploid genotype.

The aim of producing large numbers of diploid hybrid seeds by the selection of intercompatible diploid parent types, and to create from these seeds amphidiploids by colchicine treatment, could not be realized so far. Nor was an attempt to produce amphidiploids by intercrossing tetraploid parent species successful.

However, this does not exclude the possibility to use hybrids for practical breeding purposes on a tetraploid level. Perhaps diploid hybrid seeds can be produced on a larger scale by pollinating, simultaneously or successively, diploid Lolium plants with haploid and diploid pollen of meadow fescue. A haploid gamete might conjugate with an egg cell and induce an embryo. A diploid gamete might conjugate with the fusion nucleus and thus initiate endosperm.

The hybrids of diploid Lolium and triploid meadow fescue offer other possibilities. Among them aneuploids may occur; colchicine treatment of hybrid seeds may create supertetraploids which after mutual crossing may produce pure amphidiploids.

The above-mentioned ways would lead to the creation of entirely new plant types with complete genomes of Lolium and Festuca pratensis. Such plants may demand a 
treatment quite different from the diploid parent species. This will apply to a far lesser extent, if at all, when separate genes or gene complexes of $F$. pratensis can be combined with the genome of Lolium. The results of JENKINs' investigations strongly indicate that by backcrossing diploid hybrids to perennial ryegrass, genes of $F$. pratensis can be transferred to plants that are otherwise $L$. perenne and are interfertile with $L$. perenne. The same results may be obtained by backcrossing triploid and aneuploid hybrids, which can be produced on a larger scale, to diploid ryegrasses. JENkIN's triploid backcross hybrid after further backcrossing to $L$. perenne, produced an offspring which showed a strong tendency towards a return to the diploid state and to normal fertility.

However fragmentary our own data may be, they show that from artificial and natural triploid hybrids new types can be developed which in addition to a majority of morphological characters of one species also possess some characters of the other species. Among them also highly male-fertile plants occur. It seems most probable, therefore, that fertile forms can be bred which combine some physiological characters of the two parent species. Further research must prove whether such forms can be developed in a stable condition and which line should be followed for that purpose.

\section{ACKNOWLEDGEMENT}

The author wishes to express his indebtedness to Mr G. J. SpeckmanN, Foundation for Agricultural Plant Breeding, Wageningen, for counting the number of chromosomes of some of the hybrids.

\section{SAMENVATTING}

\section{Bastaarden van raaigrassen en beemdlangbloem} en hun betekenis voor de grassenveredeling

1. In een kas werden 103 kruisingen beproefd tussen 56 planten van Lolium perenne en Lolium multiflorum als moeder en 27 planten van Festuca pratensis als vader. In totaal werden 13.284 gecastreerde bloempjes van diploide, triploide en tetraploide Lolium-planten bestoven met stuifmeel van diploide en tetraploide Festuca-planten. Alleen de combinaties $2 n \times 4 n$ en $3 n \times 4 n$ leverden hybriden op, nl. gemiddeld respectievelijk 5,3 en 1,0 volwassen bastaardplanten per 100 bestoven bloempjes. $\mathrm{Bij}$ de kruisingen, die in de winter werden uitgevoerd waren deze gemiddelden resp. 12,0 en 4,9 .

2. Ongecastreerde aren van diploide, triploide en tetraploide planten van $L$. perenne en $L$. multiflorum werden op het veld in pergamine zakken ingehuld met pluimen van diploide, triploide en tetraploide planten van $F$. pratensis. Behalve van de bovengenoemde combinaties werden ook hybriden verkregen van de kruisingen $2 n$ $\times 2 n$ en $3 n \times 4 n$. Het aantal per aar geproduceerde hybriden was gemiddeld ongeveer even hoog als bij overeenkomstige kruisingen in de kas.

Door aren van zelfincompatibele diploide planten van $L$. perenne en $L$. multiflorum op het veld samen in te hullen met pluimen van tetraploide planten van $F$. pratensis kunnen gemakkelijk grote aantallen triploide bastaardzaden worden verkregen. Dit maakt zaadbehandeling met colchicine, voor het verwekken van autoallohexaploiden, in de praktijk uitvoerbaar. 
3. Triploide hybriden vertoonden een grotere voorjaarsproduktie en een betere nagroei in de zomer dan de ouderplanten. Spontaan verkregen natuurlijke bastaarden waren winterharder dan de meest winterharde inheemse typen van Engels raaigras.

4. Alle kunstmatige en de meeste natuurlijke hybriden hadden niet-openspringende meeldraden; het percentage normaal lijkend stuifmeel varieerde bij de eerste van 0 tot $3,8 \%$, bij de laatste van 0 tot $10 \%$. Verschillende planten van beide groepen waren zwak vrouwelijk fertiel. Enkele in de natuur gevonden planten met bastaardkenmerken hadden openspringende meeldraden en meer dan $75 \%$,goed" stuifmeel; zij waren vrij goed vrouwelijk fertiel.

5. Spontane zaailingen van triploide manlijk steriele hybriden gaven naast een meerderheid van planten die sterk overeenkwam met de oudersoorten of met de $F_{1}$ generatie, ook typen met nieuwe combinaties van eigenschappen. Het percentage goed stuifmeel was aanmerkelijk hoger dan in de voorgaande generatie, verschillende planten hadden openspringende meeldraden. In spontane families van de manlijk fertiele bastaardvormen kwamen sterk afwijkende vormen van Lolium voor.

6. Enkele mogelijkheden, die de verschillende kruisingscombinaties voor de veredeling van raaigrassen bieden, werden besproken.

\section{REFERENCES}

1. Carnahan, H. L. and H. D. Hill, Lolium perenne L. $\times$ tetraploid Festuca elatior L. Triploid hybrids and colchicine treatments for inducing autoallohexaploids. Agronomy Journal 47 (1955): 258-262.

2. Crowder, L. V., Interspecific and intergeneric hybrids of Festuca and Lolium. Journal of Heredity 44 (1953): 195-203.

3. ESSAD, S., Analyse cytogénétique de deux amphidiploïdes Lolium perenne L. $\times$ Festuca pratensis Huds. Comptes Rendus Acad, des Sciences (Paris) 243 (1956):670-672.

4. JENKIN, T. J., Interspecific and intergeneric hybrids in herbage grasses. Initial crosses. Journal of Genetics 28 (1934): 205-264.

5. JENKIN, T. J., Interspecific and intergeneric hybrids in herbage grasses. X. Some of the breeding interactions of Festuca gigantea. Journal of Genetics 53 (1955): 94-99.

6. JENKIN, T. J., Interspecific and intergeneric hybrids in herbage grasses. XII. Festuca capillata in crosses. Journal of Genetics 53 (1955): 105-111.

7. JENKIN, T. J., Interspecific and intergeneric hybrids in herbage grasses. XIII. The breeding affinities of Festuca heterophylla. Journal of Genetics 53 (1955): 112-117.

8. JENKIN, T. J., Interspecific and intergeneric hybrids in herbage grasses. XIV. The breeding affinities of Festuca ovina. Journal of Genetics 53 (1955): 118-124.

9. JENKIN, T. J., Interspecific and intergeneric hybrids in herbage grasses. XV. The breeding affinities of Festuca rubra. Journal of Genetics 53 (1955): 125-130.

10. JeNKIN, T. J., Interspecific and intergeneric hybrids in herbage grasses XVI. Lolium perenne and Festuca pratensis with references to Festuca loliacea. Journal of Genetics 53 (1955): 379-441. 


\section{Mededelingen van de Stichting voor Plantenveredeling \\ Publications of the Foundation for Agricultural Plant Breeding \\ Nude 66, Wageningen, Netherlands}

No. 1. LAMBERTS, H., Verbreding van de grondslagen voor de veredeling van de gele voederlupine. (Broadening the bases for the breeding of yellow sweet lupine.). 1955. Prijs $f$ 1,00. (Dissertatie).

No. 2. WIT, F., Margadant, W. D. en Dilz, K. Jarowisatie bij Engels en Italiaans raaigras (Lolium perenne en L. multiflorum). (Vernalization in perennial and Italian ryegrass). Landbouwkundig Tijdschrift 2 (1955): 137-147. Prijs f 0,25. Uitverkocht.

No. 3. Duk, G. E. VAN, The influence of sward-age and management on the type of timothy and cocksfoot (De invloed van ouderdom en de gebruikswijze op timothee en kropaar in Nederlandse graslanden). Euphytica 4 (1955): 83-93. Prijs f 0,25 . Uitverkocht.

No. 4. Huissman, C. A., Breeding for resistance to the potato root eelworm II (Het kweken op resistentie tegen het aardappel-cystenaaltje II). Euphytica 4 (1955): 133-140. Prijs f 0,25. Uitverk. No. 5. Speckmann, G. J., A rapid laboratory method for cytological control in polyploidy breeding (Een snelle methode voor cytologische controle bij polyploïdie-veredeling). Euphytica 4 (1955): 163-166. Prijs f 0,25 . Uitverkocht.

No. 6. WiERSEMA, H. T., Flax scorch (Vlasbrand). Euphytica 4 (1955): 197-205. Prijs f 0,25. Uitverk. No. 7. WIT, F. and SpeckmanN, G. J., Tetraploid Westerwolths Ryegrass (Tetraploid Westerwolds raaigras) Euphytica 4 (1955): 245-253. Prijs f 0,25. Uitverkocht.

No. 8. Thus, G. A., Methods used in evaluating potato seedlings. (De verdere opkweek van aardappelzaailingen). Euphytica 5 (1956): 55-62. Prijs f 0,25.

No. 9. Huisman, C. A., Breeding for resistance to the potato root ealworm in the Netherlands. Nematologica 1 (1956): 94-99. Prijs f 0,25. Uitverkocht.

No. 10. WIT, F., A possible virus disease in Lolium perenne. (Een virusziekte in Engels raaigras) Euphytica 5 (1956): 119-129. Prijs f 0,25. Uitverkocht.

No. 11. Diskruis, G. J., Computation of heat unit accumulations in maize for practical application. (Berekening van warmtesommen voor praktische toepassing bij maïs). Euphytica 5 (1956): 267-275. Prijs f 0,25.

No. 12. Diskstra, J., Experiences with the breeding of red clover resistant to the stem eelworm. (Enige ervatingen met het kweken van rode klaver die resistent is tegen het stengelaaltje) Euphytica 5 (1956): 298-307. Prijs f 0,25.

No. 13. Kloen, D. and SpeckmanN, G. J., The creation of tetraploid beets. IV. Morphological and physiological characteristics of $C_{2}$ beets. (Het verkrijgen van tetraploide bieten. IV morfologische en fysilogische eigenschappen van $C_{2}$ bieten) Euphytica 5 (1956): 308-322. Prijs f 0,25.

No. 14. Huissman, C. A., Veredeling van de aardappel op resistentie tegen Heterodera rostochiensis Wollenweber (Breeding for rasistance to the potato root-eelworm Heterodera rostochiensis W.), 1957. Prijs f 1,25 (Dissertatie).

No. 15. Kloen, D. and Speckmann, G. J., The creation of tetraploid beets. V. Cytological investigations on $C_{2}$ beets. (Het verkrijgen van tetraploide bieten. V. Cytologische controle van $C_{2}$ bieten). Euphytica 6 (1957): 193-197. Prijs f 0,25.

No. 16. Diskstra, J., Symptoms of susceptibility and resistance in seedlings of red clover attacked by the stem eelworm Ditylenchus dipsaci (Kühn) Filipjev. Nematologica 2 (1957): 228-237. Prijs f 0,25 .

No. 17. Huwsman, C. A., Resistance to the potato root eelworm in S. tuberosum subsp. andigena and its importance for potato breading. Neth. Journ. of Agric. Sc. Vol. 6. No. 1 (1958): 39-46. Prijs $\mathrm{f} 0,25$.

No. 18. Dantuma, G., Veredeling van tarwe en garst op winterhardheid (Breeding wheat and barley for winterhardiness), 1958. Prijs f 1,25 (Dissertatie).

No. 19. WIT, F., Tetraploid Italian ryegrass (Lolium multiflorum Lam.). (Tetraploid Italiaans raaigras) Euphytica 7 (1958): 47-58. Prijs f 0,25 .

No. 20. De eerste tien jaren. (The first ten years). 1958. Prijs $\mathrm{f} 2,50$.

No. 21. WIT, F., Hybrids of ryegrasses and meadow fescue and their value for grass breeding (Bastaarden van raaigrassen en beemdlangbloem en hun betekenis voor de grassenveredeling). Euphytica 8 (1959): 1-12. Prijs f 0,25. 


\section{Niet in de serie opgenomen publicaties van S.V.P.-medewerkers:}

LAMBER 1S, H., Some remarks on sweet lupine. Farming 2 (1948): 90-91.

LAMBERTS, H., De teelt, de veredeling en de zaaizaadvoorziening van de voederlupine. Landbouwk. Tijdschr. 60 (1948): 413-421.

LAMBERTS, H., Enting van gele voederlupine. Landbouwk. Tijdschr. 63 (1951): 187-188.

LAMBERTS, H., Resistentie tegen aantasting door Fusarium oxysporum in gele lupine. Landbouwk. Tijdschr. 63 (1951): 458-459.

ThisN, G. A., De afstamming en de nakomelingen van de Katahdin aardappel. Euphytica 1 (1952): 57-59.

ThIJN, G. A., Potato varieties and powdery mildew attacks. Euphytica 1 (1952): 84-86.

WIT, F., The pollination of perennial ryegrass (Lolium perenne L.) in clonal plantations and polycross fields. Euphytica 1 (1952) 95-104.

LAMBERTS, H., Resistance to mildew in yellow lupine. Euphytica 1 (1952): 199-200.

WIT, F., Techniques of breeding cold-resistant grasses and clovers. Proc. of the Sixth Intern. Grassland Congr. 2 (1952): 1607-1612.

LAMBERTS, H. en Tolner, J., Gele voederlupine. Teelt, gebruik en veredeling van een voedergewas. Uitgeverij Ceres. Meppel 1952, 115 pp.

LAMBERTS, H., A new type with a rapid youth growth in yellow lupine. (Lupinus luteus). Euphytica 2 (1953): 59-61.

Wrr, F., Veredelingsaspecten van het zesde internationale grasland congres. Euphytica 2 (1953): $72-75$.

SiEBEN, J. W., The correlation between resistance to lodging and fibre content in flax. Euphytica 2 (1953): 101-106.

KORSTEN, L. H. J. e.a., A colorimetric determination of the number of eelworms in a suspension. A new technic to be used in connection with the breeding of resistant clovers. Euphytica 2 (1953): $135-138$.

Toxopeus, H. J. and Huissman, C. A., Breeding for resistance to potato root eelworm. I. Preliminary data concerning the inheritance and the nature of resistance. Euphytica 2 (1953): 180-186.

Kloen, D. and SPeckmann, G. J., The creation of tetraploid beets. I. Euphytica 2 (1953): 187-196.

KORSTEN, L. H. J., Een nieuwe methode voor bepaling van de vatbaarheid van klaverplanten voor het stengelaaltje (Ditylenchus dipsaci (Kuhn) Filipjev). Tijdschr. over Plantenziekten 59 (1953): 27-28.

THIJN, G. A., Observations on flower induction with potatoes. Euphytica 3 (1954): 28-34.

KLOEN, D. and SpeckmanN, G. J., The creation of tetraploid beets. II. Selection in the first generation (the $C_{1}$ ) from the treated material. Euphytica 3 (1954): $35-42$.

SIEBEN, J. W., Het gebruik van nomogrammen ter vereenvoudiging van berekeningen. Euphytica 3 (1954): 64-67.

Thun, G. A., The raising of first year potato seedlings in glasshouses. Euphytica 3 (1954): 140-146.

KLOEN, D. and SPECKMANN, G. J., The creation of tetraploid beets. III Cytological checking in the second generation (the $C_{2}$ ) of the treated material. Euphytica 3 (1954): 154-160.

Dantuma, G., Daglengte-onderzoek bij tarwe en gerst. CoCoBro-Jaarboekje 4 (1954): 62-69.

KLOEN, D., Vernalization as a means of accelerating production of seed. Annexe 1954-1 au Bulletin de l'Institut International du Froid, Paris, $6 \mathrm{pp}$.

WIT, F. and SPECKMANN, G. J., Breeding of tetraploid ryegrasses. European Grassland Conf. organized by the Min. of Agric. for France with the co-operation of the European Productivity Agency of the Organization for European Economic Co-operation. Held in Paris 21-24 Juni 1954. Stencil $10 \mathrm{pp}$.

WIT, F., De perspectieven van chromosomenverdubbeling voor de veredeling van raaigrassen en rode klaver. Landbouwk. Tijdschr. 66 (1954): 533-536. 